\title{
A Problem with Empirical Studies of Party Policy Shifts: Alternative Measures of Party Shifts are Uncorrelated
}

\author{
James Adams (University of California, Davis, Department of Political Science) \\ Luca Bernardi (Universitat Autònoma de Barcelona, Department of Political Science and Public Law) \\ Lawrence Ezrow (University of Essex, Department of Government) \\ Oakley B. Gordon (University of California, Davis, Department of Political Science) \\ Tzu-Ping Liu (University of California, Davis, Department of Political Science) \\ M. Christine Phillips (Texas A\&M University, Department of Political Science)
}

\begin{abstract}
Many recent cross-national studies analyze the causes and electoral consequences of party policy shifts, using party position measures derived from (1) election manifestos, (2) expert surveys, or (3) voter surveys. However few studies validate their findings by analyzing multiple measures of party policy shifts. We analyze data on European parties' position shifts on both European integration and Left-Right ideology and show that this is problematic, because while alternative measures of party policy positions correlate strongly in cross-sectional analyses, alternative measures of parties' policy shifts are essentially uncorrelated in longitudinal analyses. We offer suggestions on how to address this problem.
\end{abstract}

Keywords: party policy shifts; expert surveys; party manifestos; voters' perceptions of parties' positions

Forthcoming in the European Journal of Political Research. Version accepted for publication on October 27, 2018. 
Over the past decade, dozens of empirical studies analyze the causes and consequences of party policy change in western democracies (for overviews see Adams 2012; Dalton \& McAllister 2015). The growth in such studies reflects the availability of data sets providing measures of party positions across countries and time, including codings of parties' election manifestos published by the Comparative Manifesto Project and the Euromanifestos Project; surveys of political experts published by the Chapel Hill Expert Survey team; and rank-and file voters' perceptions of party positions available via the Comparative Study of Electoral Systems and the European Election Studies. Empirical studies based on these data sets analyze how parties shift their policies in response to factors such as public opinion, past election results, economic conditions, and rival parties' strategies, and how public opinion reciprocally reacts to party shifts (e.g., Spoon \& Klüver 2014).

While there is a lively debate over the merits of alternative party position measures (see, e.g., Benoit et al. 2009), studies report that alternative measures converge in comparisons of different parties' policy positions measured at the same time (e.g., Bakker et al. 2015). However, studies of party policy shifts compare the same party's position measured at different times, and no extant study analyzes whether alternative measures of party position shifts based on election manifestos, expert surveys, and voter surveys converge with each other. This question is important because if the answer is no, then scholars' substantive conclusions about the causes and consequences of party policy shifts may depend on their choice of party position measure. In fact, there is a simple reason to expect alternative measures of party policy shifts to diverge sharply, even as alternative measures of different parties' positions converge: namely, the differences between different parties' policy positions - such as the policy differences between socialist versus conservative parties, or between green versus radical right parties - are often large, 
whereas the difference between the same party's positions across short- to medium-term time periods - such as the elapsed time between successive national elections - is typically small. ${ }^{1} \mathrm{We}$ substantiate this contention below, but readers may find it intuitively obvious: political parties in western democracies exist largely as vehicles to promote opposing viewpoints, and so competitive party systems typically feature rival parties espousing sharply divergent policies; by contrast, parties are often reluctant to shift their policies over time, fearing that such policy reversals may ignite intra-party divisions and prompt electorally damaging accusations that they are "flipflopping" (Tomz \& Van Houweling 2014). And, the well-known statistical principle of attenuation bias states that the strength of the observed association between two variables that correlate imperfectly - such as alternative party policy position measures - weakens as the measured range of the variable values narrows (see, e.g., Draper \& Smith 1998). ${ }^{2}$ In analyses of party position change, the problem is that in the absence of significant "true" party change, unreliable change scores are to be expected. ${ }^{3}$ That is, with modest-sized "true" party position changes the

${ }^{1}$ For empirical evidence on the diversity of different parties' policy positions, see, e.g., Bakker et al. (2015). For evidence on party policy stability over time see, e.g., Dalton (2015). ${ }^{2}$ This is related to the long-standing point in the psychometric literature that change scores are subject to reliability problems (e.g., Gilford 1954).

${ }^{3}$ Dalton \& McAllister (2015) raise this point, noting that mean voter perceptions of parties' current Left-Right positions can be almost perfectly predicted from lagged voter perceptions. They state that "Despite the common discussions of party change in contemporary democracies, these results show remarkable persistence in party positions. If one accepts the presence of some measurement error, such as sampling error in the surveys or the impact of short-term exogenous 
ratio of true to (true + random) variance is small, and alternative measures of party change will diverge. ${ }^{4}$ Hence we expect the correlation between alternative measures of parties' policy shifts, which are typically modest, to be weaker than correlations between alternative measures of different parties' positions, because inter-party policy differences are often large.

\section{Empirical applications}

The only two dimensions for which alternative longitudinal, cross-nationally comparable party position measures are available across many countries are Left-Right ideology and - for European politics - the more focused issue of European integration. Both dimensions offer party position measures based on election manifesto codings, expert surveys, and voter surveys. We analyze each dimension in turn.

The European integration dimension. Table 1 substantiates our argument with respect to the issue of European integration using three alternative party position measures: the Euromanifesto Project (EMP) codings of the manifestos parties published in the run-up to European Parliamen-

events, then this...correlation between elections is impressive. It seems to leave little room for real electoral change, except in a few exceptional cases."

${ }^{4}$ This argument applies provided that the errors associated with the focal party position measure are not strongly correlated across time. If, alternatively, the errors correlate strongly across time, the measure may yield a reliable estimate of party position change even if the estimate of the party's position at any given time point is unreliable. (An example would be a measure that systematically skews the party's estimated position in a leftward (rightward) direction, but where this measurement skew is identical at every time point where the party's position is measured). We thank an anonymous reviewer for raising this point. 
tary elections (held every five years, most recently in 2014); the mean party placements provided by rank-and-file survey respondents to the European Election Study (EES) surveys, which are administered in all European Union member states around the time of these elections; and the mean party placements provided by the political experts surveyed in the Chapel Hill Expert Surveys (CHES), that have been administered at several points beginning in 1999. Section 1 in the supplementary materials memo describes these data sets. The EMP manifesto codings scale runs from -100 to +100 ; the CHES expert survey scale from 1 to 7; the EES voter survey scale from 0 to 10. In each case higher numbers denote a more positive stance on European integration.

Row 1 in Table 1A displays the mean party system policy divergence, defined as the average standard deviation of the measured positions of the parties in each system, averaged across the 16 European Union member states in 2009 for which we have comparable measures based on the Euromanifesto Project (EMP) codings, the Chapel Hill Expert Surveys (CHES), and the European Election Study (EES) respondents' mean party placements. ${ }^{5}$ (Table S1 in the supplementary materials memo reports the set of countries and parties included in these analyses.) Row 2 in Table 1A reports the mean party position shifts on European integration between 2009 and 2014 (the dates of the two most recent European Parliamentary elections) for these alternative position measures, where a party's position shift is defined as the absolute value of the difference between its measured positon in 2014 versus $2009 .^{6}$ These computations confirm that these par-

\footnotetext{
${ }^{5}$ The EES and EMP data sets both provide party position estimates for 2009. The relevant CHES surveys were administered in 2006 and 2010, and we interpolated these data to obtain estimates of the parties' positions for 2009.

${ }^{6}$ We note that the EMP, CHES, and EES data sets all provide party position estimates for 2014, so that no data interpolation was necessary for that year. (For the EES data we analyzed the se-
} 
ty systems typically featured parties offering sharply different positions on European integration (row 1), but that parties' measured policy shifts between 2009 and 2014 were modest (row 2).

Tables 1B-1C display the correlations between the EMP-, CHES-, and EES-based measures of party positions in 2009 (Table 1B), versus the correlations between alternative measures of party position shifts between 2009-2014 (Table 1C). These estimates are computed for the 68 parties for which we have comparable party position measures across all three data sets (Table S1 in the supplementary materials memo lists these parties). These computations substantiate our argument that alternative measures of different parties' positions should converge much more strongly than alternative measures of party position shifts: The correlations between alternative measures of party positions, reported in Table 1B, are all large and significant (the weakest is +0.76 ), while the correlations across alternative measures of party position shifts, reported in Table 1C, are all small and insignificant (the strongest is +0.19 ). This latter pattern implies that scholars' substantive conclusions about why parties shift position on European integration may depend on their choice of measure.

\section{[TABLE 1 ABOUT HERE]}

The Left-Right dimension. Table 2 substantiates our arguments with respect to the Left-Right ideological dimension, using three alternative party position measures: the Comparative Manifesto Project (CMP) codings of the manifestos parties published in the run-ups to national parliamentary elections; the mean Left-Right party placements provided in national election surveys compiled by the Comparative Study of Electoral Systems (CSES) data base; and experts' mean Left-Right party placements provided by the Chapel Hill Expert Surveys (CHES). Section 2 in

cond post-election 2014 EES survey, which included a version of the European integration question that was identical to the questions asked in earlier EES waves.) 
the supplementary materials memo discusses these data sets, and the cases we analyze. We note that because the CHES-based expert surveys are of European party systems, our comparisons of alternative party position measures are confined to European parties. The CMP manifesto codings scale runs from -100 to +100 ; the CHES expert survey scale from 0 to 10 ; the CSES voter survey scale from 0 to 10 . In each case higher numbers denote more right-wing positions.

Row 1 in Table 2A displays the mean party system divergence computed for our alternative party position measures, while row 2 reports the mean party position shifts, computed for the years of the two most recent national parliamentary elections for the 11 European party systems for which we have comparable CMP, CSES, and CHES data. ${ }^{7}$ These computations confirm that European party systems typically offer the electorate a choice between diverse Left-Right party positions, but that parties' measured over-time Left-Right shifts were quite modest, on average. Meanwhile Tables 2B-2C display the correlations between the CMP-, CSES-, and CHES-based measures of party Left-Right positions (Table 2B), versus the correlations between these alternative measures of party position shifts (Table 2C), which again substantiate our arguments: The correlations across alternative measures of party positions, reported in Table 2B, are all large and significant (the weakest is +0.71 ), while the correlations across measures of party position shifts, reported in Table $2 \mathrm{C}$, are all weak and insignificant (the strongest is +0.25 ).

\section{[TABLE 2 ABOUT HERE]}

Analyses of all available party position data. Our analyses in Tables 1-2 above are of party position shifts measured across the two most recent time points for which we have comparable measures based on party manifesto codings, expert surveys, and voter surveys. Here we extend

\footnotetext{
${ }^{7}$ In all cases the CMP- and CSES-based measures are from the years of national parliamentary elections. We interpolated the CHES data to match the years of the CMP and CSES measures.
} 
our analyses of these three party position shift measures - for both European integration and Left-Right ideology - to all available time points for which we have overlapping data based on these measures. These analyses begin in 1999, the first year in which the CHES surveys were administered. Table $3 \mathrm{~A}$ reports the computed correlations between alternative measures of party position shifts on European integration, computed for the set of $\mathrm{N}=184$ shifts across 1999-2014 for which we have comparable party position measures across all three data sets. (The supplementary materials memo provides additional details about these calculations, while Table S3 in the memo lists the countries, parties, and years that we included for these analyses.) These computations substantiate our conclusion that alternative measures of parties' position shifts on European integration are all near zero and insignificant (the strongest is +.08$){ }^{8}{ }^{8}$

Table 3B reports the computed correlations between alternative measures of parties' LeftRight shifts, computed for the set of $\mathrm{N}=94$ shifts across 2000-2013 for which we have comparable party position measures across all three data sets. (The supplementary information memo provides additional details about these calculations, while Table S5 lists the countries, parties, and years included in these analyses.) These computations substantiate our finding that the correlations across alternative measures are all small and insignificant (The strongest is +0.18$).{ }^{9}$

\footnotetext{
${ }^{8}$ By contrast, the cross-sectional correlations between the EMP-, EES-, and CHES-based measures of party positions on European integration are strong and highly significant across the 1999-2014 period. These correlations, for the set of $\mathrm{N}=268$ cases, are: $r=+0.70$ for the EMPEES $(\mathrm{p}<0.01) ; r=+0.77$ for the EMP-CHES $(\mathrm{p}<0.01) ; r=+0.74$ for the EES-CHES $(\mathrm{p}<0.01)$.

${ }^{9}$ The cross-sectional correlations between the CMP-, CSES-, and CHES-based measures of party Left-Right positions are strong and highly significant across the 1999-2014 period. These corre-
} 


\section{[TABLE 3 ABOUT HERE]}

\section{What, then, Shall we do? Conclusion and Discussion}

We began this note by observing that while democratic party systems typically offer voters a diverse set of policy choices, individual parties' issue positions are often static in the shortto-medium term. These observations are not new. Moreover, the statistical implication of these patterns, namely that alternative measures of party policy shifts will not converge to the same degree as alternative measures of different parties' positions, due to the statistical principle of attenuation bias, strikes us as obvious. What was not obvious (to the authors, at least) is how severe this problem is, in practice. We find no meaningful correlation between alternative measures of party position shifts on European integration and Left-Right ideology based on analyses of manifesto codings, expert surveys, and national elections surveys, even though these alternative measures of different parties' positions correlate strongly. Since Left-Right and European integration are the only two dimensions for which we have extensive cross-national and longitudinal party position estimates across different measures, these are currently the only dimensions on which we can empirically evaluate our arguments. Our analyses of both dimensions confirm that this is a severe problem - and thus there is no reason to expect the substantive conclusions scholars draw from analyses of any single measure of party position change to be robust to the use of alternative measures. Yet most empirical studies of the causes and electoral consequences of party policy shifts employ a single party position measure. The authors themselves have published many such studies (e.g., Adams and Ezrow 2009), yet were unaware - until now - of the complete non-convergence of alternative measures of party position change.

lations, for the set of $\mathrm{N}=149$ cases, are: $r=+0.71$ for the CMP-CSES $(\mathrm{p}<0.01) ; r=+0.93$ for the CHES-CSES $(p<0.01) ; r=+0.77$ for the CMP-CHES $(p<0.01)$. 
How can scholars address the problem we identify? While we can only briefly discuss this issue in this research note, we recommend, first, that scholars explore the robustness of their findings using alternative measures of party position shifts, and when this is not possible that scholars emphasize to readers the conditional nature of findings based on any single party position measure. Second, for certain research questions scholars might present a strong theoretical rationale for privileging one specific measure. Thus in studies of voter reactions to party policy shifts what arguably matters is how the voters themselves perceive these shifts, so that scholars might base their studies on voters' party placements. By contrast, studies of how government policy outputs respond to parties' position shifts might privilege the statements in governing parties' election manifestos, since previous research documents that parties are punished for reneging on their manifesto-based promises. We therefore suggest that scholars move away from analyzing generic "party policy change", and focus instead on specific types of party change (manifesto-based change, change as perceived by voters, etc.) that are appropriate to the research question being studied. A third, statistically-based approach to the problem we have identified is to analyze party policy shifts over longer time periods than the elapsed time between consecutive elections (to the national or the European parliament), which has been the standard approach in extant studies. It seems plausible that the longer the time period over which party policy shifts are measured the greater the magnitudes of these shifts (on average), which should ameliorate the statistical problem of the "noise" relating to measurement error drowning out the "signal" of the parties' true shifts - and this should in turn strengthen the correlation between alternative party position shift measures. However this empirical strategy comes with a cost, namely that as the analyst defines each measured party shift as encompassing a longer time period the number of cases in the data set shrinks, which depresses the power of the statistical analyses. 
We close with two caveats that also suggest possible pathways forward. First, scholars have recently begun developing promising party position measures beyond the expert-, voter-, and manifesto-based measures we analyze here. These include estimates of parties' policy positions based on their press releases (e.g., Sagarzazu \& Klüver 2017) or collected from national press agencies and newswires (Bernardi et al. 2018); on party leaders' annual speeches (e.g., Hobolt \& Klemmensen 2008); and on parties' more general campaign communications (SomerTopcu \& Tavits 2018). These new measurement techniques have not yet been applied to a sufficient number of party systems (and across sufficiently long time periods) to permit the types of comparisons between party position shift measures that we report here, but these new measures may converge with each other (and with the measures we analyze here) more strongly than do the measures analyzed in this paper. Second, our empirical findings apply only to the Left-Right and European integration dimensions of party competition, which are the only two dimensions for which we can currently conduct the types of cross-national, longitudinal analyses we present. Although most studies of party shifts are along one of these two dimensions, there are a handful of cross-national empirical studies analyzing party shifts on more focused dimensions, including multiculturalism (e.g., Abou-Chadi \& Krause 2018; Han 2015) and environmental issues (Spoon 2011; Bischof 2018). In the future, as scholars extend their party position studies to additional policy dimensions and across longer time periods, we plan to evaluate whether the statistical issues we identify for Left-Right ideology and European integration are equally severe with respect to these other dimensions. In this regard, our arguments take as their starting point that different parties' positions at one time point tend to differ much more than do the same party's positions over time. It remains to be seen whether this condition applies to dimensions beyond LeftRight and European integration. We also note that the statistical problem we identify in analyses 
of party shifts may apply equally to cross-sectional analyses that are restricted to comparisons of like-minded parties' positions (as for instance if we restricted our Left-Right analyses to mainstream parties near the center). ${ }^{10}$

Finally, our findings raise two questions for future research. First, the study raises deeper issues about how to define a party’s “policy position” (see Marks 2007). Second, does nonconvergence between alternative party policy shift measures arise because one or more of these measures is seriously flawed, or because these measures are designed to capture different facets of party policy positions? These are fundamental questions, yet extant studies of party policy change rarely address them. Our findings may prompt scholars to consider these questions, as they study the causes and consequences of party policy shifts.

${ }^{10}$ Another implication of our study is that scholars - in designing national surveys or expert surveys - may actually want to directly ask citizens and experts to estimate parties' policy changes over time (see Di Virgilio et al. 2015 based on Benoit \& Laver's 2006 approach). We thank an anonymous reviewer for raising this point. 


\section{References}

Abou-Chadi, T. \& Krause W. (2018). The Causal Effect of Radical Right Success on Mainstream Parties' Policy Positions - a Regression Discontinuity Approach. British Journal of Political Science.

Adams, J. (2012). The Causes and the Electoral Consequences of Party Policy Shifts in Multiparty Elections. Annual Review of Political Science 15: 401-419.

Adams, J. \& Ezrow, L. (2009). Who do European Parties Represent? How Western European Parties Represent the Policy Preferences of Opinion Leaders. Journal of Politics 71(1): 206-223.

Bakker, R., de Vries, C., Edwards, E., Hooghe, L., Jolly, S., Marks, G., Polk, J., Rovny, J., Steenbergen, M., \& Vachudova, M. (2015). Measuring Party Positions in Europe: The Chapel Hill Expert Survey Trend File, 1999-2010. Party Politics 21(1): 143-52.

Benoit, K. \& Laver, M. (2006). Party Policy in Modern Democracies. London: Routledge.

Benoit, K., Mikhaylov, S., \& Laver, M. (2009). Treating Words as Data with Error: Uncertainty in Text Statements of Policy Positions. American Journal of Political Science 53(2): $495-$ 513.

Bernardi, L., Sabaté, O., Visconti, F. \& Morales, L. (2018). Governing Status and Intra-Party Disagreement in Europe. Paper prepared for presentation at the ResponsiveGov Project Final Workshop, Sciences Po, Paris, 19 February 2018.

Bischof, D. (2018). How do Parties React to Protest? The Moderating Effects of Party Ideology and Public Opinion. Typescript available at: https://danbischof.com/publications/

The Comparative Study of Electoral Systems (www.cses.org). CSES MODULE 4 FULL RELEASE [dataset and documentation]. May 29, 2018 version. Doi:107804/cses.module4.2018-0529. 
Dalton, R.J. (2015). Stability and Change in Party Issue Positions across the 2009 and 2014 European Elections. Typescript.

Dalton, R. \& McAllister, I. (2015). Random Walk or Planned Excursion? Continuity and Change in the Left-Right Positions of Political Parties. Comparative Political Studies 48(6): 759 87.

Di Virgilio, A., Giannetti D., Pedrazzani, A. \& Pinto, L. (2015). Party Competition in the 2013 Italian Elections: Evidence from an Expert Survey. Government and Opposition 50(1): 6589.

Draper, N.R. \& Smith, H. (1998). Applied Regression Analysis (3rd ed.). New York: John Wiley.

van Egmond, M., van der Brug, W., Hobolt, S., Franklin, M. \& Sapir, E.V. (2013). European Parliament Election Study 2009, Voter Study. GESIS Data Archive, Cologne. ZA5055 Data file Version1.1.0, doi:10.4232/1.11760.

van der Eijk, C., Franklin, M., Schoenbach, K., Schmitt, H., Semetko, H., with van der Brug, W., Holmberg, S., Mannheimer, R., Marsh, M., Thomassen, J., Wessels, B., International Research Group “European Election Studies”, IPSOS, Hamburg, Germany (primary investigator) (): European Election Study - 1999. DANS.http://dx.doi.org/10.17026/dans-z9j-vy6m.

Giebler, H., Lichteblau, J., May, A., Melcher, R., Wagner, A. \& Weßels, B. CSES MODULE 1-3 HARMONIZED TREND FILE [dataset]. May 31, 2016 version. Doi:

107804/cses.trendfile.2016-05-31.

Guilford, J.P. (1954). Psychometric Methods (2 ${ }^{\text {nd }}$ Edition). New York: McGraw Hill. Hobolt, S.B. \& Klemmensen, R. (2008). Government Responsiveness and Political Competition in Comparative Perspective. Comparative Political Studies 41(3): 309-337. 
Marks, G. (2007). Triangulation and the Square Root Law. Electoral Studies 26: 1-10.

Polk, J., Rovny, J., Bakker, R., Edwards, E., Hooghe, L., Jolly, S., Koedam, J., Kostelka, F., Marks, G., Schumacher, G., Steenbergen, M., Vachudova, M. \& Zilovic, M. (2017). Explaining the salience of anti-elitism and reducing political corruption for political parties in Europe with the 2014 Chapel Hill Expert Survey data. Research \& Politics (January-March): 1-9.

Sagarzazu, I. \& Klüver, H. (2017). Coalition Governments and Party Competition: Political Communications Strategies of Coalition Parties. Political Science Research and Methods 5(2): $333-49$.

Schmitt, H., Bartolini, S., van der Brug, W., van der Eijk, C., Franklin, M., Fuchs, D., Toka, G., Marsh, M. \& Thomassen, J. (2009). European Election Study 2004 ( $2^{\text {nd }}$ edition). GESIS Data Archive, Cologne. ZA4566 Data file Version 2.0.0, doi:10.4232/1.10086.

Schmitt, H., Braun, D., Popa, S.A., Mikhaylov, S. \& Dwinger, F. (2018). European Parliament Election Study 1979-2014, Euromanifesto Study. GESIS Data Archive, Cologne. ZA5102 Data file Version 2.0.0, doi:10.4232/1.12830.

Schmitt, H., Popa, S.A. \& Devinger, F. (2015). European Parliament Election Study 2014, SVoter Study, Supplementary Study. GESIS Data Archive, Cologne. ZA5161 Data file Version 1.0.0, doi:10.4232/1.5161.

Somer-Topcu, Z. \& Tavits, M. (2018). Does Message Distortion by Rivals Affect Party Policy Images? Typescript.

Spoon, J.-J. (2011). Political Survival of Small Parties in Europe. Ann Arbor: University of Michigan Press.

Spoon, J.-J. \& Klüver, H. (2014). Do Parties Respond? How Electoral Context Influences Party Competition. Electoral Studies 35(1): 48-60. 
Tomz, M. \& van Houweling, R. (2014). Political Repositioning: A Conjoint Analysis. Typescript.

Volkens, A., Lehmann, P., Matthieß, T., Merz, N., Regel, S. \& Weßels, B. (2018). The Manifesto Data Collection. Manifesto Project (MRG/CMP/MARPOR). Version 2018a. Berlin: Wissenschaftszentrum Berlin für Sozialforschung (WZB).

https://doi.org/10.25522/manifesto.mpds.2018a. 


\section{Table 1. Analyses of Alternative Measures of Party Policy Positions and Position Shifts: The European Integration Dimension}

Table 1A. Measured Policy Differences on European Integration between Different Parties' Positions in 2009, and between the Same Parties' Positions in 2009 versus 2014

\begin{tabular}{||l|c|c|c||}
\hline \hline & $\begin{array}{c}\text { EMP } \\
\text { codings } \\
(-100 \text { to }+100) \\
(1)\end{array}$ & $\begin{array}{c}\text { EES party } \\
\text { placements } \\
(0 \text { to } 10) \\
(2)\end{array}$ & $\begin{array}{c}\text { CHES party } \\
\text { placements } \\
(1 \text { to } 7) \\
(3)\end{array}$ \\
\hline $\begin{array}{l}\text { Mean party system policy } \\
\text { divergence in 2009 }(\mathrm{N}=16)\end{array}$ & 13.98 & 1.22 & 1.65 \\
\hline $\begin{array}{l}\text { Mean absolute value of parties' policy } \\
\text { shifts between 2009-2014 }(\mathrm{N}=68)\end{array}$ & 7.05 & 0.77 & 0.40 \\
\hline
\end{tabular}

1B. Correlations between Alternative Party Position Measures, 2009 data ( $N=74)$

\begin{tabular}{||l|c|c|c||}
\hline \hline & $\begin{array}{c}\text { EMP } \\
\text { codings }\end{array}$ & $\begin{array}{c}\text { EES party } \\
\text { placements }\end{array}$ & $\begin{array}{c}\text { CHES party } \\
\text { placements }\end{array}$ \\
\hline EMP codings & -- & $0.76^{* *}$ & $0.78^{* *}$ \\
\hline EES party placements & & -- & $0.84^{* *}$ \\
\hline \hline
\end{tabular}

1C. Correlations between Alternative Party Position Shift Measures, 2009-2014 data ( $\mathrm{N}=68$ )

\begin{tabular}{|l|c|c|c||}
\hline \hline & $\begin{array}{c}\text { EMP } \\
\text { codings }\end{array}$ & $\begin{array}{c}\text { EES party } \\
\text { placements }\end{array}$ & $\begin{array}{c}\text { CHES party } \\
\text { placements }\end{array}$ \\
\hline EMP codings & -- & 0.19 & 0.00 \\
\hline EES party placements & & -- & -0.13 \\
\hline
\end{tabular}

${ }^{* *} p \leq .01 ; * p \leq .05$, two-tailed tests.

Notes. In Table 1A, "Mean party system policy divergence, 2009" is the average of the standard deviations of the parties' policy positions in 16 European Union member states in 2009, measured via the Euromanifesto (EMP) codings (column 1), European Election Study (EES) survey respondents' mean party placements (col. 2), and the Chapel Hill Expert Survey (CHES) respondents' mean party placements (col. 3). As noted in the column headings, the EMP-based scale runs from -100 to +100 , the EES scale from 0-10, and the CHES scale from 1-7, where higher numbers denote more positive attitudes towards EU integration. Table S1 in the supplementary materials memo lists the parties and countries included in these analyses. 


\section{Table 2. Analyses of Alternative Measures of Party Policy Positions and Position Shifts: The Left-Right Dimension}

Table 2A. Measured Left-Right Differences between Different Parties' Positions at the Same Time Point, and between the Same Parties' Positions over Time

\begin{tabular}{||l|c|c|c||}
\hline \hline & $\begin{array}{c}\text { CMP } \\
\text { Codings } \\
(-100 \text { to }+100) \\
(1)\end{array}$ & $\begin{array}{c}\text { CSES party } \\
\text { Placements } \\
(0 \text { to } 10) \\
(2)\end{array}$ & $\begin{array}{c}\text { CHES party } \\
\text { Placements } \\
(0 \text { to } 10 \\
(3)\end{array}$ \\
\hline $\begin{array}{l}\text { Mean party system divergence in } \\
\text { second-to-last national election (N=11) }\end{array}$ & 19.36 & 2.11 & 2.28 \\
\hline $\begin{array}{l}\text { Mean absolute value of parties' shifts bet- } \\
\text { tween the last two national elections }(\mathrm{N}=46)\end{array}$ & 9.19 & 0.30 & 0.26 \\
\hline \hline
\end{tabular}

2B. Correlations between Alternative Party Position Measures $(\mathrm{N}=52)$

\begin{tabular}{||l|c|c|c||}
\hline & $\begin{array}{c}\text { CMP } \\
\text { codings }\end{array}$ & $\begin{array}{c}\text { CSES party } \\
\text { placements }\end{array}$ & $\begin{array}{c}\text { CHES party } \\
\text { placements }\end{array}$ \\
\hline CMP codings & -- & $0.71^{* *}$ & $0.78^{* *}$ \\
\hline CSES party placements & & -- & $0.95^{* *}$ \\
\hline
\end{tabular}

2C. Correlations between Alternative Party Position Shift Measures $(\mathrm{N}=46)$

\begin{tabular}{||l|c|c|c||}
\hline \hline & $\begin{array}{c}\text { CMP } \\
\text { codings }\end{array}$ & $\begin{array}{c}\text { CSES party } \\
\text { placements }\end{array}$ & $\begin{array}{c}\text { CHES party } \\
\text { placements }\end{array}$ \\
\hline CMP codings & -- & 0.06 & 0.25 \\
\hline CSES party placements & & -- & -0.18 \\
\hline
\end{tabular}

** $p \leq .01 ; * p \leq .05$, two-tailed tests.

Notes. Only pairs of party-year observations available in all three of the CMP, CSES, and CHES data sets are considered. Countries and national elections included in this analysis: Czech Republic (2010, 2013), Finland (2007, 2011), France (2007, 2012), Germany (2009, 2013), Ireland (2007, 2011), Netherlands (2006, 2010), Poland (2007, 2011), Portugal (2005, 2009), Spain (2004, 2008), Sweden $(2002,2006)$, and the United Kingdom $(2001,2005)$. Table S2 in the supplementary materials memo lists the parties included in these analyses. 


\section{Table 3. Correlations between Alternative Measures of Party Position Shifts: All Available Comparisons, 1999-2014}

3A. The European Integration Dimension ( $\mathrm{N}=184)$

\begin{tabular}{||l|c|c|c||}
\hline \hline & $\begin{array}{c}\text { EES party } \\
\text { placements } \\
(1)\end{array}$ & $\begin{array}{c}\text { EMP } \\
\text { codings } \\
(2)\end{array}$ & $\begin{array}{c}\text { CHES party } \\
\text { placements } \\
(3)\end{array}$ \\
\hline $\begin{array}{l}\text { EES party } \\
\text { placements }\end{array}$ & -- & 0.08 & 0.07 \\
\hline EMP codings & & -- & 0.03 \\
\hline
\end{tabular}

3B. The Left-Right Dimension ( $\mathrm{N}=94)$

\begin{tabular}{||l|c|c|c||}
\hline \hline & $\begin{array}{c}\text { CSES party } \\
\text { placements } \\
(1)\end{array}$ & $\begin{array}{c}\text { CMP } \\
\text { codings } \\
(2)\end{array}$ & $\begin{array}{c}\text { CHES party } \\
\text { placements } \\
(3)\end{array}$ \\
\hline $\begin{array}{l}\text { CSES party } \\
\text { placements }\end{array}$ & -- & -0.00 & 0.11 \\
\hline CMP codings & & -- & 0.18 \\
\hline
\end{tabular}

$* p<.05$.

Notes. Table $3 \mathrm{~A}$ reports the correlations between alternative measures of party position shifts on European integration as computed based on party position measures derived from European Election Study (EES) (van der Eijk et al. 1999; Schmitt et al. 2009; van Egmond et al. 2013; Schmitt et al. 2015) respondents' mean party placements; the Euromanifesto Project (EMP) (Schmitt et al. 2018) codings of parties' Euromanifestos, published in the run-up to elections to the European Parliament; and the Chapel Hill Expert Survey respondents' party placements (CHES) (Polk et al. 2017; Bakker et al. 2015), over the period 1999-2014. Table 3B reports the correlations between alternative measures of party Left-Right position shifts as computed based on party position measures derived from national election survey respondents' mean party placements derived from the Comparative Study of Electoral Systems (CSES) (Giebler et al. 2016; The Comparative Study of Electoral Systems 2018) data set; the Comparative Manifesto Project (CMP) (Volkens et al. 2018) Left-Right codings of parties' national election manifestos, published in the run-up to national parliamentary elections; and the CHES respondents' LeftRight party placements. The set of parties, countries, and years included in these analyses are presented in Tables S3 S5 in the supplementary information memo. 